ENTREPRENEURSHIP AND SUSTAINABILITY ISSUES

ISSN 2345-0282 (online) http://jssidoi.org/jesi/

2021 Volume 9 Number 2 (December)

http://doi.org/10.9770/jesi.2021.9.2(10)

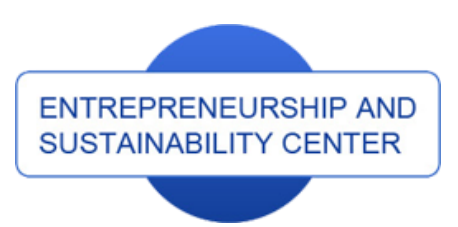

Publisher
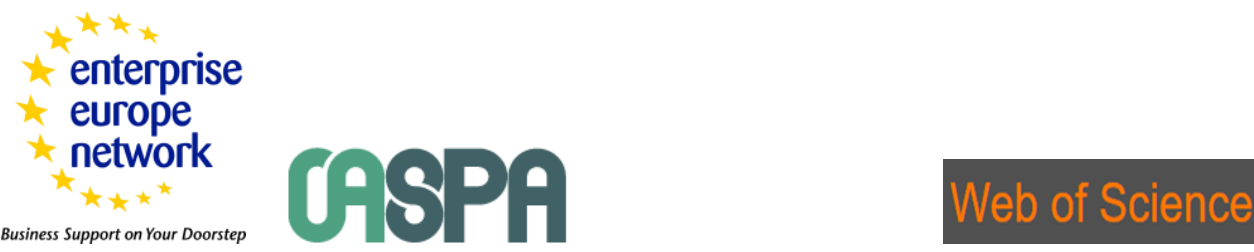

http://jssidoi.org/esc/home

1 Clarivate

Analytics

\title{
LONGITUDINAL RESEARCH - ENTREPRENEURIAL ORIENTATION IMPACT, INNOVATIVENESS, AND BUSINESS PERFORMANCE IN CROATIAN COMPANIES
}

\author{
Helena Šlogar \\ Libertas International University, Trg J. F. Kennedyja 6b, HR-10000 Zagreb, Croatia \\ E-mail: $\underline{\text { hlogar@libertas.hr }}$
}

Received 18 May 2021; accepted 25 September 2021; published 30 December 2021

\begin{abstract}
The research explores whether there were changes in the model of the impact that entrepreneurial orientation (EO) had on innovativeness and business performance in Croatian companies, in the 2016-2019 period. To analyse data, we used regression and covariance analysis. The results reveal that the impact of entrepreneurial orientation and proactiveness on innovativeness and business performance did not show a significant statistical change between the years 2016 and 2019 in Croatian companies. However, the impact of risk-taking on innovativeness showed a statistically significant change. The change in the impact of risk-taking on business performance, and the change in the impact that autonomy had on innovativeness and business performance, could not be statistically reliably established. The results can benefit companies to better understand the entrepreneurial orientation and thus to increase the level of innovativeness in their operations. In the long run, this leads to the market competitiveness of their company. The results also contribute to the development of scientific thoughts about entrepreneurial success as the ultimate goal of entrepreneurship. Besides its contribution to the research of entrepreneurship, this article has meaningful implications for policy-makers and managers.
\end{abstract}

Keywords: innovativeness, entrepreneurial orientation, risk-taking, proactiveness, Croatian companies

Reference to this paper should be made as follows: Šlogar, H. 2021. Longitudinal research - Entrepreneurial orientation impact, innovativeness, and business performance in Croatian companies. Entrepreneurship and Sustainability Issues, 9(2), 152-168. http://doi.org/10.9770/jesi.2021.9.2(10)

JEL Classifications: L26, 031, F1

\section{Introduction}

In the past three decades, the interest of scientists in studying companies' innovativeness has surged. This is the result of academic research in various concepts of strategic orientations of companies that affect their innovativeness and business performance. The reasons for this specific interest can be found in "The Schumpeterian approach theory“, widely seen within the research of entrepreneurship (Schumpeter 1934; 


\section{ENTREPRENEURSHIP AND SUSTAINABILITY ISSUES}

ISSN 2345-0282 (online) http://jssidoi.org/jesi/ 2021 Volume 9 Number 2 (December) http://doi.org/10.9770/jesi.2021.9.2(10)

Carlsson et al. 2013; Acs et al. 2013). This approach offers an evolutionary perspective that combines knowledge, entrepreneurship as a process, and regional transformation through time (Henning, McKelvey 2020; Malerba, McKelvey 2020). Acs (2006) states that Schumpeter's idea depends on long-term economic growth and its ability to use innovation. Baumol (1990) differentiates productive, unproductive, and destructive entrepreneurship. Desai et al. (2013) state that this division has important implications especially for countries that are still recovering from wars and other conflicts. Productive entrepreneurship refers to entrepreneurial activities that create economic value and can vary depending on the productivity of the entrepreneur and on the institutions which impact the entire economy. Unproductive entrepreneurship involves activities that redistribute the existing rents, annuities, tax evasion, etc. Various studies analyze the difference between productive and unproductive entrepreneurship (Sobel 2008; Herrmann, 2019). Destructive entrepreneurship is "a discovery of a previously unused legal gambit that is effective in diverting rents to those who are first in exploiting it." (Baumol 1990, p. 897). Desai et al. (2013) define destructive entrepreneurship as the one which is destroying wealth. They suggest a development model of destructive entrepreneurship and make assumptions about the nature and behavior of entrepreneurial talent.

On the one hand, entrepreneurship is related to economic growth, innovation, employment, and productivity (Acs 2006). On the other, a series of studies have confirmed that the ownership of companies does not necessarily stimulate economic growth (Audretsch, Thurik 2001; Hessels et al. 2008). Luu \& Ngo (2019) claim that the entrepreneurial constructs are applicable in various cultural contexts, particularly in transition economies. Moreover, entrepreneurial orientation (EO) has successfully been applied in different types of organizations, including state-owned companies (Tremml, 2019). Various studies have examined how institutions affect entrepreneurship and the results indicate that public institutions are important for the growth of entrepreneurial ventures (Bjørnskov, Foss 2013; Herrmann, 2019). The dynamics of entrepreneurship development differs depending on institutional context and on the level of economic development of industrial sectors in a country (Acs et al. 2008). Studies have also shown that economic, cultural, and historical outcomes have a significant impact on entrepreneurial activity and risk-taking (Grilo, Thurik 2005). Entrepreneurial orientation has been well explored in industrialized Western business environments (Lumpkin, Dess 2001; Bernoster et al. 2020), while in the non-Western context their applicability has not been adequately researched (Killa, 2014; Ejdys, 2016; Głodowska et al. 2019; Raats, Krakauer, 2020). Using a sample of Chinese companies Wong (2012) proves that entrepreneurial orientation positively affects the success of new products. Killa (2014) confirmed the impact of entrepreneurial orientation, innovativeness, product innovation, and value creation on the marketing performance of companies in Indonesia. Ejdys (2016) confirms the positive relationship between entrepreneurial orientation and innovativeness in companies in the Poslaskie Region. Several scientists have explained the role of entrepreneurial orientation in the process of developing innovations, finding that it affects business performance in a certain country (Presutti et al. 2017; Presutti, Odorici 2019).

The research question is posed here: 1. What type of impact does entrepreneurial orientation exert on innovativeness and performance in Croatian companies, and how much has it changed in the two examined time periods? Croatia is a small country with an open market. These circumstances require longitudinal research, as well as the comparison of the results of the 2016 and the 2019 research, to ascertain whether there are changes in the impact of entrepreneurial orientation on innovativeness and business performance. This research has embraced the approach advocated by Oslo Manual (2005) who used a 3-year time frame to understand the changes in innovation developments. Given that innovativeness is a time-consuming process, rarely completed within one financial year, the longitudinal research offers a better insight into the innovation activities within a company than a one-year approach. The focus of this analysis is on different types of innovativeness that companies implement for products, processes, and systems (Nybakk, 2012). 


\section{ENTREPRENEURSHIP AND SUSTAINABILITY ISSUES}

ISSN 2345-0282 (online) http://jssidoi.org/jesi/

2021 Volume 9 Number 2 (December)

http://doi.org/10.9770/jesi.2021.9.2(10)

The stagnation of the Croatian economy began in the 1980s due to the crisis of the political and economic system at the time. Privatization was initiated in the 1990s albeit in the unfavorable circumstances of the war. The real aim of privatization was not achieved since state assets were not managed by productive entrepreneurs. The collapse of the system ensued with a sharp decline in production, exporting, employment, consumption, and the standard of living. The previous system of workers' self-management was very soon transformed into "wild capitalism". Monetary politics based on a more or less fixed exchange rate was supposed to create a framework for the restructuring of companies. Unfortunately, it ended up being a limiting factor in the transition of the Croatian economy, present until today. This type of politics has brought uneven growth and development of an economic model based on trade, imports, and consumption, which is not stimulating for the development of entrepreneurship. Large companies generate most of their income in the domestic market, which is the consequence of the economic and political system, and not primarily of the result of able entrepreneurs. This destructive process was successfully going on at a time when the strategic goal of other transition countries in Eastern and Central Europe was the one of increasing domestic production and employment.

The beginning of the global crisis in 2008 produced different trends, two of which are particularly important: the continuation of the country's indebtedness, and the limitations arising from the structure of investments. In that period the state played the role of the main entrepreneur, so the infrastructure and nonproductive capacities saw the largest amount of investment, while too little was invested in production capacities. However, the new traffic infrastructure was beneficial for tourism development. The Global Entrepreneurship Monitor (GEM) report published in 2018 revealed that the level of entrepreneurship in Croatia was still low in comparison to the average level in Europe (Singer et al. 2018). Croatia joined the European Union in 2013 as the 28th member-state. After the accession, the exports of small and medium-sized companies to the EU have grown, while the share of large companies in the total exports has decreased. Industrial production is technologically inferior and has resulted in a decline in production, employment and exports.

Croatia's accession to the European Union pulled the economy out of a prolonged recession - a positive aspect of Croatia's transitional process. However, if we examine the structural issues of the Croatian economy, the picture of entrepreneurship development looks grim. Investments in Croatia are significantly smaller than in other eurozone countries, public administration reforms are slow and the labor productivity in Croatia is below the EU average. Croatian companies are less interested in innovativeness which indicates that business systems are sluggish in using the openness of the market to find innovative solutions. The results of the Global Entrepreneurship Monitor (GEM) show that even though Croatian companies are better technologically equipped than those in the EU, and in the comparative group of countries whose economies are efficiency-driven, in terms of product innovation Croatia is lagging behind (Singer et al. 2018). These are very worrying indicators because competitiveness is achieved through innovative products and not through the technological equipment of companies. In the 2016-2018 period about $70 \%$ of TEAs and more than $75 \%$ of "growing" companies in Croatia had products that were not new to anyone (Singer, et al. 2018). If we compare Croatia to Italy, which is the second most important Croatia's foreign trade partner, Italy is better than Croatia in both categories of business ventures: TEA and mature firms. Italy had twice as many companies which produced completely new products not known before in the TEA category, and as much as 3.6 times more new products, previously unknown, produced by mature firms (Singer et.al. 2018).

The efficiency of public administration in Croatia is also below the EU average, which weakens the entrepreneurs' trust in the state government. The efficiency of the judicial system is low and Croatia is at the top of the EU in terms of unresolved court cases. Even though the public debt decreased towards the end of 2019, it was still the highest of all the countries in Central and Eastern Europe. A large part of the public debt increase has been the repercussion of the retirement reform that was introduced through the second retirement column, which has created this gap in relation to other countries. Public debt is still creating structural vulnerability of the domestic economy. These are just some of the examples of structural problems in the economy that have affected the 


\section{ENTREPRENEURSHIP AND SUSTAINABILITY ISSUES}

ISSN 2345-0282 (online) http://jssidoi.org/jesi/

2021 Volume 9 Number 2 (December)

http://doi.org/10.9770/jesi.2021.9.2(10)

development of entrepreneurship. Insufficient cooperation between industry and science influences the creation of a legislative framework, and this framework is the basis for carrying out research and development projects that would increase the technological and innovative activities of companies. Most investments are based on further withdrawals from the EU cohesion funds. On top of that, in main Croatia's foreign trade partners, Germany and Italy, economic growth is expected to gradually slow down in the short term. However, despite all the negative indicators, the ruling politics in Croatia does not analyze the successes and failures of the previous policies, to use them as the basis for producing significant changes and thus help the development of entrepreneurship.

In several respects, this study contributes to the exploration of strategic orientations of company management. The impact of entrepreneurial orientation on the innovativeness and performance of Croatian companies was examined for the first time by longitudinal research in the 2016 and in 2019 research. The application of the same model, and the usage of the same sample of companies, will shed more light on the model itself. As for the applied model, the findings will show whether business success will be achieved and whether managers should take the same course of action as they did in the year 2016. We depict here entrepreneurial orientation through generic entrepreneurial experience specific to a particular industry, to better understand the role of this orientation in the development of innovative processes. Moreover, the results contribute to a deeper understanding of EO's impact on the innovativeness and performance of Croatian companies. Most research studies refer to American and West European countries, while this study provides data on a European transition country. Based on the theoretical knowledge on entrepreneurial orientation, there was a need to prove the hypothesis about the impact of entrepreneurial orientation on innovativeness and business performance of Croatian companies. This study is organized as follows: First, the literature review is given on the entrepreneurial orientation, including innovativeness and business performance. Then the description of the research methods is presented, as well as the findings of the research. Last, the conclusion is drawn with theoretical and practical implications.

\section{Literature review}

A one-dimensional construct for measuring EO is largely used in studies, based on what entrepreneurial companies have in common (Covin, Slevin 1989); while a multi-dimensional concept explores how entrepreneurial companies can differ, and the concept is expanded with two dimensions: competitive aggressiveness and autonomy (Lumpkin, Dess 1996). Lumpkin et al. (2013) suggest that the presence of multiple stakeholders and access to funding/financing impact risk-taking, competitive aggressiveness, and autonomy. Raats \& Krakauer (2020) state that it is necessary to combine the dimensions of competitive aggressiveness and autonomy for the construct of EO to exist in a dynamic environment. Several studies provide an overview of all the significant research on the concept of EO (Covin, Miller 2014; Wales, 2016). Scientists are focused on various aspects of innovativeness, such as developing business strategy and business model (Ireland et al. 2009); on new products (Rosenbusch et al. 2011); on innovation process (Perez-Luno et al., 2011); innovation performances (Alegre, Chiva 2013); types of innovation (Covin et al., 2016 ); innovation culture (Gupta, Gupta 2015) and the key to success in business which leads to better performance, better company's position in the market and to competitiveness (Certo et al. 2009). Such factors can encourage the efforts of entrepreneurs in overcoming many obstacles they face in developing business processes (Acs et al., 2008). Numerous studies state that innovativeness is not a uniformly identified variable, so the testing of structured models with overlapping dimensions is often proposed, for example, in the domain of International Entrepreneurial Orientation (IEO) (Dai et al. 2014; Thanos et al. 2017; Głodowska et al. 2019; Raats, Krakauer 2020); or testing with mutually exclusive constructs (Covin, Miller 2014). Finally, there are cases where the relevant forms of innovativeness have been limited to those connected with the new inputs in the fields of technology, business models, products, services or markets (Covin, Wales 2019). 


\section{ENTREPRENEURSHIP AND SUSTAINABILITY ISSUES}

ISSN 2345-0282 (online) http://jssidoi.org/jesi/

2021 Volume 9 Number 2 (December)

http://doi.org/10.9770/jesi.2021.9.2(10)

It seems appropriate to ask a question now whether it is acceptable to combine the dimensions of entrepreneurial orientations in different ways. Many authors argue that theoretically defined dimensions of entrepreneurial orientation can be combined since they constitute a collective "catchcall" (Miller, 2011; Covin, Lumpkin 2011). Different combinations of the EO dimensions have been researched in numerous studies (Rauch et al. 2009; Wales et al. 2015; Wales, 2016 ). Miller (2011) encourages researchers to extend the theoretical reach by applying the models which use a taxonomy of variables related to strategic, organizational, leadership, cultural, and environmental variables. Numerous discussions have been opened up about the nature of the concept and the difference between the reflecting and formative model of EO in different contexts (George, Marino 2011). Covin \& Wales (2012) study these problems and favor the reflective model for measuring the EO dimensions. On the other hand, Anderson et al. (2015) use the formative model. It can also be argued that the EO scale was developed and used primarily for companies and therefore such measurement scales have limited application in other organizational contexts, due to differences in set goals, management structure, etc. For example, in the public and private sector (Zahra et al. 2014; Khanagha et al. 2017); in education (Todorovic et al. 2011; Ismail et al. 2015; Diánez-González, Camelo-Ordaz 2017); and in international business (Thanos et al. 2017).

Although there is a large body of literature on conceptualizing and measuring entrepreneurial orientation, and discussions are often initiated on the subject, there is actually a small number of high value-added studies (Covin, Wales 2019). Therefore it is necessary to continue the research and add value to the concept of entrepreneurial orientation. Scientists have obtained mixed results in comparing EO and performance. However, in most studies, they have proved the existence of a positive and strong relationship between the two, in various economic contexts (Khedhaouria et al. 2015; Guzmán et al. 2020). Entrepreneurial orientation is an important factor in entrepreneurial success, which is the ultimate goal of entrepreneurship (Bernoster et al. 2020). The relationship between entrepreneurial orientation (EO) and business performance is one of the most researched subjects in entrepreneurship (Wiklund, Shepherd 2011). Several studies indicate that dynamic effects of EO on the business operations of a company can be caused by internal elements, such as the level of entrepreneurial experience, limited resources, and company size, as well as by external elements, such as inter-organizational networks, environmental protection, etc. (Presutti et al., 2017). In the study by Presutti \& Odorici (2019), the results measured in 2005 and in 2016 indicate that previous entrepreneurial experience, when specific, can increase the effect of entrepreneurial and market orientation on the growth of business performance in small and medium-size Italian IT firms. Wales (2016) states that many researchers have already suggested there should be further quality research on the topic of EO (Miller, 2011; Wiklund, Shepherd 2011; Covin, Miller 2014).

Based on the defined objective, this research tested the following hypothesis:

H1: Entrepreneurial orientation positively and directly impacts innovativeness and business performance, and this impact was not significantly changed in the 2019 model, in relation to the 2016. 


\section{ENTREPRENEURSHIP AND SUSTAINABILITY ISSUES}

ISSN 2345-0282 (online) http://jssidoi.org/jesi/

2021 Volume 9 Number 2 (December)

http://doi.org/10.9770/jesi.2021.9.2(10)

\section{Research methodology}

The main goals of the 2019 research were based on the identical model, hypotheses, and the identical survey questionnaire as those in the 2016 research, so that the data collected in both research studies are compatible and suitable for comparison. The results of the first collected set of data from the 2016 research were published in the paper (Šlogar, Bezić 2020). The model applied includes entrepreneurial orientation as an independent variable, which includes three dimensions: proactivity, risk-taking inclination (Covin, Slevin 1989); and the level of autonomy in Croatian companies (Lumpkin, Dess 1996). A Likert scale with rating scales ranging from 1 to 5 was used. Dependent variables include innovativeness with three dimensions: product innovations, process innovativeness, and business system innovativeness (Nybakk 2012); and business performance with quantitative and qualitative effects. The Likert five-point scale (1-5) is also used for rating. The information was collected via e-mails sent to 900 Croatian companies that were actively operating and were registered in the Register of Business entities of the Croatian Chamber of Commerce. For the longitudinal survey, only a sub-sample of companies that participated in both surveys was selected. Finally, 101 company was included, from 303 companies which participated in the 2016 survey; and 101 company, of all 158 respondents, from the 2019 survey. The questionnaire was created in online Google Docs which simplifies filling it out and submitting it, in order to get the largest possible number of respondents. The data for the two research studies were gathered online in two periods: the first set of data from October till December 2016, whilst the second one was from October 2019 till January 2020.

The needed size of a representative sample was determined by using the Power Analysis method. It found that the sample of 101 companies, with $95 \%$ reliability and $90 \%$ of the power test, with a correlation coefficient bigger than 0,30, will give statistically significant results. This is the expected correlation between dependent and independent variables, established based on the 2016 research. Thus we can state that the sample of 101 companies will provide statistically reliable results. The gathered data were first analyzed by descriptive statistics in order to check whether the values of the independent and dependent variables followed the normal distribution. If the mean value does not deviate significantly from the median value, it can be concluded that there is no significant deviation from the normal distribution. Therefore, for further statistical analysis, parametric methods, regression analysis, and covariance analysis were used. The regression analysis checked whether there was a statistically significant influence between independent and dependent variables in 2016 and 2019. Statistically significant regression lines are a prerequisite for applying a covariance analysis. The covariance analysis tests the difference between the regression lines from 2016 and 2019, i.e. it tests the difference between the inclination of the lines and the sections of the lines. If the inclination and sections of the lines are approximately equal, the lines will be parallel and close to one another, which means that there is no significant difference between these lines, and thus there is no actual difference between the mutual influence of independent and dependent variables in 2016 and 2019. The result of the analysis of covariance is statistically reliable if the inclination of the regression lines is statistically significant, so with $95 \%$ reliability it can be stated that the regression line has exactly the depicted inclination and section. If the regression line is not statistically significant, then this can not be confirmed. That is why unreliable cases will be commented in the regression analysis before performing the covariance analysis (ANCOVA), and the covariance analysis will be conducted only for reliable cases, for the 2016-2019 period. 


\section{Research results}

In this chapter, the analysis of the survey results will be presented. Complex data will be analyzed with a table or graph.

Table 1. Descriptive statistics of variables included in the 2016 and 2019 model

\begin{tabular}{|c|c|c|c|c|c|c|}
\hline 2016 & $\mathrm{~N}$ & Mean & Median & Minimum & Maximum & Std.Dev. \\
\hline Entrepreneurial orientation & 101 & 86.3 & 86.0 & 64 & 113 & 11.86 \\
\hline Proactiveness & 101 & 19.2 & 20.0 & 9 & 25 & 4.43 \\
\hline Risk-taking & 101 & 17.5 & 17.0 & 12 & 24 & 2.86 \\
\hline Autonomy & 101 & 15.0 & 15.0 & 7 & 23 & 2.98 \\
\hline Innovativeness & 101 & 56.9 & 57.0 & 25 & 79 & 11.93 \\
\hline Product innovation & 101 & 20.9 & 22.0 & 6 & 30 & 5.36 \\
\hline Process innovativeness & 101 & 14.4 & 15.0 & 4 & 20 & 3.95 \\
\hline Business system innovativeness & 101 & 17.4 & 17.0 & 11 & 24 & 3.61 \\
\hline Business performance & 101 & 59.3 & 58.0 & 39 & 77 & 9.03 \\
\hline $\begin{array}{c}\text { Business performance- Quantitative } \\
\text { effects }\end{array}$ & 101 & 23.6 & 23.0 & 12 & 33 & 4.27 \\
\hline $\begin{array}{c}\text { Business performance- Qualitative } \\
\text { effects }\end{array}$ & 101 & 31.8 & 32.0 & 20 & 45 & 5.41 \\
\hline 2019 & $\mathrm{~N}$ & Mean & Median & Minimum & Maximum & Std.Dev. \\
\hline Entrepreneurial orientation & 101 & 86.7 & 90.0 & 41 & 104 & 11.16 \\
\hline Proactiveness & 101 & 19.9 & 20.0 & 5 & 25 & 4.22 \\
\hline Risk-taking & 101 & 16.7 & 17.0 & 5 & 24 & 2.58 \\
\hline Autonomy & 101 & 13.9 & 14.0 & 5 & 20 & 2.78 \\
\hline Innovativeness & 101 & 59.7 & 60.0 & 27 & 80 & 13.36 \\
\hline Product innovation & 101 & 22.6 & 23.0 & 6 & 30 & 5.92 \\
\hline Process innovativeness & 101 & 14.8 & 16.0 & 6 & 20 & 4.11 \\
\hline Business system innovativeness & 101 & 18.5 & 19.0 & 9 & 25 & 4.23 \\
\hline Business performance & 101 & 61.5 & 61.0 & 44 & 80 & 9.67 \\
\hline $\begin{array}{c}\text { Business performance- Quantitative } \\
\text { effects }\end{array}$ & 101 & 24.0 & 24.0 & 16 & 31 & 3.85 \\
\hline $\begin{array}{c}\text { Business performance- Qualitative } \\
\text { effects }\end{array}$ & 101 & 33.7 & 33.0 & 22 & 45 & 6.18 \\
\hline
\end{tabular}

Source: Author

Table 1. Descriptive statistics show that there is no significant difference between the arithmetic middle (Mean) and the median value (Median), which means that the values of the variables do not deviate significantly from the normal distribution. Although it is justified to apply regression analysis and covariance analysis in further statistical processing, it can be seen that the values of the statistical indicators from 2016 and 2019 do not differ, which indicates that no significant changes in the model are expected from 2016 till 2019. 
Table 2. Regression Analysis - Impact of independent variables in 2016 and 2019.

\begin{tabular}{|c|c|c|c|c|c|c|c|c|}
\hline \multicolumn{9}{|c|}{ Dependent Variable: Innovativeness } \\
\hline \multirow{2}{*}{$\begin{array}{c}\text { Independent } \\
\text { variable }\end{array}$} & \multicolumn{4}{|c|}{2016} & \multicolumn{4}{|c|}{2019} \\
\hline & $\mathrm{R}$ & SE & $\mathrm{F}(1.99)$ & $\mathrm{p}$ & $\mathrm{R}$ & SE & $\mathrm{F}(1.99)$ & $\mathrm{p}$ \\
\hline $\begin{array}{c}\text { Entrepreneurial } \\
\text { orientation }\end{array}$ & 0.751 & 0.065 & 132.957 & $<0.001$ & 0.670 & 0.075 & 80.494 & $<0.001$ \\
\hline Proactiveness & 0.747 & 0.066 & 129.661 & $<0.001$ & 0.720 & 0.070 & 106.849 & $<0.001$ \\
\hline Risk-taking & 0.356 & 0.092 & 14.994 & $<0.001$ & 0.230 & 0.098 & 5.507 & 0.021 \\
\hline Autonomy & 0.337 & 0.093 & 13.161 & $<0.001$ & -0.079 & 0.100 & 0.616 & 0.434 \\
\hline \multicolumn{9}{|c|}{ Dependent Variable: Product innovation } \\
\hline \multirow{2}{*}{ Independent variable } & \multicolumn{4}{|c|}{2016} & \multicolumn{4}{|c|}{2019} \\
\hline & $\mathrm{R}$ & SE & $\mathrm{F}(1.99)$ & $\mathrm{p}$ & $\mathrm{R}$ & SE & $\mathrm{F}(1.99)$ & $\mathrm{p}$ \\
\hline $\begin{array}{c}\text { Entrepreneurial } \\
\text { orientation }\end{array}$ & 0.679 & 0.074 & 84.726 & $<0.001$ & 0.659 & 0.076 & 75.960 & $<0.001$ \\
\hline Proactiveness & 0.652 & 0.076 & 73.120 & $<0.001$ & 0.702 & 0.072 & 96.249 & $<0.001$ \\
\hline Risk-taking & 0.330 & 0.095 & 12.131 & 0.001 & 0.260 & 0.097 & 7.151 & 0.009 \\
\hline Autonomy & 0.381 & 0.093 & 16.800 & $<0.001$ & -0.037 & 0.100 & 0.133 & 0.716 \\
\hline \multicolumn{9}{|c|}{ Dependent Variable: Process innovativeness } \\
\hline \multirow{2}{*}{ Independent variable } & \multicolumn{4}{|c|}{2016} & \multicolumn{4}{|c|}{2019} \\
\hline & $\mathrm{R}$ & SE & F (1.99) & $\mathrm{p}$ & $\mathrm{R}$ & SE & $\mathrm{F}(1.99)$ & $\mathrm{p}$ \\
\hline $\begin{array}{c}\text { Entrepreneurial } \\
\text { orientation }\end{array}$ & 0.643 & 0.077 & 69.688 & $<0.001$ & 0.547 & 0.084 & 42.327 & $<0.001$ \\
\hline Proactiveness & 0.587 & 0.081 & 51.925 & $<0.001$ & 0.587 & 0.081 & 52.109 & $<0.001$ \\
\hline Risk-taking & 0.427 & 0.091 & 22.096 & $<0.001$ & 0.173 & 0.099 & 3.039 & 0.084 \\
\hline Autonomy & 0.355 & 0.094 & 14.241 & $<0.001$ & -0.094 & 0.100 & 0.882 & 0.350 \\
\hline \multicolumn{9}{|c|}{ Dependent Variable: Business system innovativeness } \\
\hline \multirow{2}{*}{ Independent variable } & \multicolumn{4}{|c|}{2016} & \multicolumn{4}{|c|}{2019} \\
\hline & $\mathrm{R}$ & SE & $\mathrm{F}(1.99)$ & $\mathrm{p}$ & $\mathrm{R}$ & SE & $\mathrm{F}(1.99)$ & $\mathrm{p}$ \\
\hline $\begin{array}{c}\text { Entrepreneurial } \\
\text { orientation }\end{array}$ & 0.537 & 0.085 & 40.217 & $<0.001$ & 0.660 & 0.076 & 76.250 & $<0.001$ \\
\hline Proactiveness & 0.584 & 0.082 & 51.218 & $<0.001$ & 0.722 & 0.070 & 107.662 & $<0.001$ \\
\hline Risk-taking & 0.217 & 0.098 & 4.887 & 0.029 & 0.192 & 0.099 & 3.778 & 0.055 \\
\hline Autonomy & 0.175 & 0.099 & 3.140 & 0.079 & -0.069 & 0.100 & 0.471 & 0.494 \\
\hline
\end{tabular}


Table 2. depicts the results of the regression analysis. The results indicate that in 2016 the entrepreneurial orientation, together with all its dimensions: proactiveness, risk-taking, and autonomy had a statistically significant impact $(\mathrm{p}<0,001)$ on company innovativeness, product innovation, and process innovativeness. The autonomy dimension did not have a statistically significant impact on business systems innovativeness $(p>0,05)$. Risk-taking had a slightly weaker impact on the business system innovativeness, but the impact is statistically significant $(\mathrm{p}<0,05)$. It is also shown that in the year 2019 the company innovativeness, as well as its dimensions were statistically significantly positively influenced by entrepreneurial orientation and proactiveness $(\mathrm{p}<0.001)$. Risk-taking positively influenced innovativeness and product innovation $(\mathrm{p}<0,05)$, while, on the other hand, it did not have a statistically significant impact on process innovativeness and business system innovativeness $(p>0,05)$.

Table 3. Impact of independent variables on business performance in 2016 and 2019

\begin{tabular}{|c|c|c|c|c|c|c|c|c|}
\hline \multicolumn{9}{|c|}{ Dependent Variable: Business performance } \\
\hline \multirow{2}{*}{$\begin{array}{c}\text { Independent } \\
\text { variable }\end{array}$} & \multicolumn{4}{|c|}{2016} & \multicolumn{4}{|c|}{2019} \\
\hline & $\mathrm{R}$ & SE & $\mathrm{F}(1.99)$ & $\mathrm{p}$ & $\mathrm{R}$ & SE & $\mathrm{F}(1.99)$ & $\mathrm{p}$ \\
\hline $\begin{array}{c}\text { Entrepreneurial } \\
\text { orientation }\end{array}$ & 0.700 & 0.070 & 98.692 & $<0.001$ & 0.543 & 0.084 & 41.488 & $<0.001$ \\
\hline Proactiveness & 0.720 & 0.068 & 110.736 & $<0.001$ & 0.608 & 0.080 & 59.952 & $<0.001$ \\
\hline Risk-taking & 0.391 & 0.091 & 18.565 & $<0.001$ & 0.082 & 0.100 & 0.666 & 0.416 \\
\hline Autonomy & 0.331 & 0.093 & 12.693 & $<0.001$ & -0.177 & 0.099 & 3.195 & 0.077 \\
\hline \multicolumn{9}{|c|}{ Dependent Variable: Business performance - Quantitative effects } \\
\hline \multirow{2}{*}{ Independent variable } & \multicolumn{4}{|c|}{2016} & \multicolumn{4}{|c|}{2019} \\
\hline & $\mathrm{R}$ & SE & $F(1.99)$ & $\mathrm{p}$ & $\mathrm{R}$ & SE & $F(1.99)$ & $\mathrm{p}$ \\
\hline $\begin{array}{c}\text { Entrepreneurial } \\
\text { orientation }\end{array}$ & 0.475 & 0.088 & 28.804 & $<0.001$ & 0.435 & 0.090 & 23.122 & $<0.001$ \\
\hline Proactiveness & 0.463 & 0.089 & 27.053 & $<0.001$ & 0.453 & 0.090 & 25.522 & $<0.001$ \\
\hline Risk-taking & 0.422 & 0.091 & 21.478 & $<0.001$ & 0.115 & 0.100 & 1.318 & 0.254 \\
\hline Autonomy & 0.186 & 0.099 & 3.549 & 0.063 & -0.121 & 0.100 & 1.474 & 0.228 \\
\hline \multicolumn{9}{|c|}{ Dependent Variable: Business performance - Qualitative effects } \\
\hline \multirow{2}{*}{ Independent variable } & \multicolumn{4}{|c|}{2016} & \multicolumn{4}{|c|}{2019} \\
\hline & $\mathrm{R}$ & SE & F (1.99) & $\mathrm{p}$ & $\mathrm{R}$ & SE & $\mathrm{F}(1.99)$ & $\mathrm{p}$ \\
\hline $\begin{array}{c}\text { Entrepreneurial } \\
\text { orientation }\end{array}$ & 0.717 & 0.070 & 104.766 & $<0.001$ & 0.536 & 0.085 & 39.875 & $<0.001$ \\
\hline Proactiveness & 0.723 & 0.069 & 108.125 & $<0.001$ & 0.629 & 0.078 & 64.853 & $<0.001$ \\
\hline Risk-taking & 0.353 & 0.094 & 14.079 & $<0.001$ & 0.045 & 0.100 & 0.204 & 0.653 \\
\hline Autonomy & 0.457 & 0.089 & 5.106 & $<0.001$ & -0.185 & 0.099 & 3.497 & 0.064 \\
\hline
\end{tabular}

Source: Author

Autonomy dimension did not have a statistically significant impact on innovativeness, product innovation, process innovativeness and business system innovativeness in the year 2019 (p>0,05). In these cases, where the 


\section{ENTREPRENEURSHIP AND SUSTAINABILITY ISSUES}

ISSN 2345-0282 (online) http://jssidoi.org/jesi/ 2021 Volume 9 Number 2 (December) http://doi.org/10.9770/jesi.2021.9.2(10)

regression analysis showed that there is no statistically significant correlation between independent and dependent variables, no covariance analysis was performed to test the statistical difference between the regression lines in 2016 and 2019.

Table 3 shows that in 2016, entrepreneurial orientation and all three of its dimensions had a positive, statistically significant impact on business performance and its quantitative and qualitative effects $(\mathrm{p}<0.001)$. In 2019 entrepreneurial orientation $(\mathrm{p}<0.001)$ and its dimension of proactiveness $(\mathrm{p}<0,001)$ had a statistically significant impact on business performance and its quantitative and qualitative effects, while, risk-taking and autonomy did not have a statistically significant impact $(\mathrm{p}>0.05)$. As the regression analysis showed that there is no significant correlation between risk-taking, autonomy, and business performance, with its quantitative and qualitative effects, no covariance analysis was performed to test the statistical difference between the regression lines in 2016 and 2019.

Table 4. Analysis of Covariance (ANCOVA) Comparison of the impact of independent variables on innovation in 2016 and 2019

\begin{tabular}{|c|c|c|c|c|c|c|c|c|}
\hline \multirow{2}{*}{$\begin{array}{c}\text { Effect 2016 vs 2019 } \\
\end{array}$} & \multicolumn{2}{|c|}{ Innovativeness } & \multicolumn{2}{c|}{ Product innovation } & \multicolumn{2}{c|}{$\begin{array}{c}\text { Process } \\
\text { innovativeness } \\
\text { system } \\
\text { innovativeness }\end{array}$} \\
\cline { 2 - 8 } & $\mathrm{F}$ & $\mathrm{p}$ & $\mathrm{F}$ & $\mathrm{p}$ & $\mathrm{F}$ & $\mathrm{p}$ & $\mathrm{F}$ & $\mathrm{p}$ \\
\hline Entrepreneurial orientation & 3.674 & 0.057 & 6.257 & 0.013 & 0.295 & 0.588 & 5.183 & 0.024 \\
\hline Proactiveness & 1.233 & 0.268 & 3.111 & 0.079 & 0.003 & 0.958 & 2.770 & 0.098 \\
\hline Risk-taking & 5.035 & 0.026 & 8.249 & 0.005 & $/$ & $/$ & $/$ & $/$ \\
\hline Autonomy & $/$ & $/$ & $/$ & $/$ & $/$ & $/$ & $/$ & $/$ \\
\hline
\end{tabular}

Source: Author

Table 4 shows the results of covariance analysis which tested the statistical difference between the regression lines of all pairs of independent and dependent variables in 2016 and 2019. Covariance analysis shows that there is no statistically significant difference between the impact of entrepreneurial orientation on innovativeness in 2016 and 2019 ( $p>0.05)$. Furthermore, it is shown that there is no statistically significant difference between the impact of entrepreneurial orientation and proactiveness on company innovativeness in 2016 and 2019 ( $p>0.05$ ). There is a statistically significant difference between the impact of risk-taking on the company innovativeness in 2016 and 2019 ( $p<0.05)$. The given results reveal there is no difference between the impact of proactiveness on product innovation in 2016 and in 2019 ( $\mathrm{p}>0.05$ ). Furthermore, there is a statistically significant difference between the impact of entrepreneurial orientation and risk-taking on product innovation in 2016 and 2019 (p < 0.05). No statistically significant difference was found between company orientation and proactiveness on process innovativeness in 2016 and in 2019 ( $\mathrm{p}>0.05$ ). The covariance analysis shows that there is no statistically significant difference between the impact of proactiveness on business system innovativeness in 2016 and in 2019 ( $p>0.05)$. There is a statistically significant difference between the impact of entrepreneurial orientation on business system innovativeness in 2016 and in 2019 ( $p<0.05)$. 
ENTREPRENEURSHIP AND SUSTAINABILITY ISSUES

ISSN 2345-0282 (online) http://jssidoi.org/jesi/ 2021 Volume 9 Number 2 (December) http://doi.org/10.9770/jesi.2021.9.2(10)

Table 5. Comparison of the impact of independent variables on business performance in 2016 and 2019

\begin{tabular}{|c|c|c|c|c|c|c|}
\hline \multirow[t]{2}{*}{ Effect 2016 vs 2019} & \multicolumn{2}{|c|}{ Business performance } & \multicolumn{2}{|c|}{$\begin{array}{l}\text { Business performance- } \\
\text { Quantitative effects }\end{array}$} & \multicolumn{2}{|c|}{$\begin{array}{c}\text { Process } \\
\text { Innovativeness } \\
\text { Qualitative effects }\end{array}$} \\
\hline & $\mathrm{F}$ & $\mathrm{p}$ & $\mathrm{F}$ & $\mathrm{p}$ & F & $\mathrm{p}$ \\
\hline Entrepreneurial orientation & 2.232 & 0.137 & 0.186 & 0.667 & 6.707 & 0.010 \\
\hline Proactiveness & 1.233 & 0.268 & 0.000 & 0.995 & 3.842 & 0.051 \\
\hline Risk-taking & l & l & / & l & I & l \\
\hline Autonomy & I & 1 & l & l & l & l \\
\hline
\end{tabular}

Source: Author

Table 5 presents the results of covariance analysis which tested the statistical difference between the regression lines of individual independent variables and business performance in 2016 and in 2019. The covariance analysis result is reliable if both regression lines show a statistically significant connection between an independent variable and business performance. This condition is not met in the case of risk-taking and business performance, and in the case of autonomy and business performance, so the covariance analysis was not performed here. The covariance analysis shows there is no statistically significant difference between the impact of entrepreneurial orientation on business performance, and between the impact of proactiveness on business performance in 2016 and in 2019 ( $\mathrm{p}>0.05$ ). It also shows there is no statistically significant difference between the impact of entrepreneurial orientation on the quantitative effects of business performance and between the impact of proactiveness on the quantitative effects of business performance in 2016 and in 2019 ( $p$ > 0.05). The covariance analysis reveals there is a significant statistical difference between the impact of entrepreneurial orientation on the qualitative effects of business performance in 2016( $\mathrm{p}<0.05)$, while there is no statistically significant difference between the impact of proactiveness on the qualitative effects of business performance in 2016 and in 2019 (p > $0.05)$.

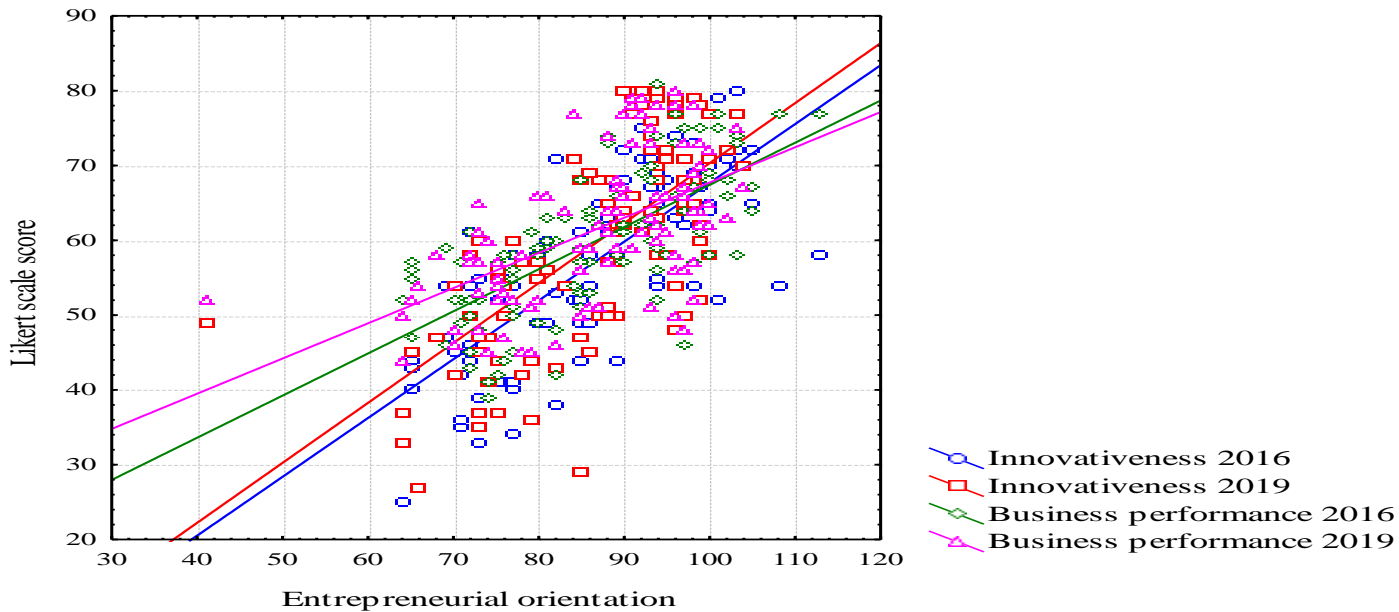

Graph 1. The impact of entrepreneurial orientation on innovativeness and business performance

Source: Author 


\section{ENTREPRENEURSHIP AND SUSTAINABILITY ISSUES}

ISSN 2345-0282 (online) http://jssidoi.org/jesi/

2021 Volume 9 Number 2 (December)

http://doi.org/10.9770/jesi.2021.9.2(10)

Graph 1 presents the score of the answers about the impact of entrepreneurial orientation on innovativeness, and it was somewhat higher in 2019 than it was in the 2016 research, while the regression lines are almost parallel, which means that the level of dependency remained unchanged. The answers about the impact of entrepreneurial orientation on business performance in 2019 show that there are more answers with the lower score; that the intersection of lines is at around 90, which means that there is roughly an equal number of scores at around 90, both in the 2016 and 2019 research; while the scores above 90 prevail in the 2016 research.

Following the given results, we can confirm hypothesis H: Entrepreneurial orientation positively and directly impacts innovativeness and business performance, and this impact was not significantly changed in the 2019, in relation to the 2016. More detailed analysis of the impact that segments of entrepreneurial orientation had on innovativeness, indicated that all three segments of entrepreneurial orientation (proactiveness, risk-taking and autonomy) had a statistically significant positive impact on all segments of innovativeness (product innovativeness, process innovativeness, and business system innovativeness) in 2016 and in 2019. The exception is autonomy in 2019, where there was no significant impact of autonomy on other innovativeness segments. Similarly, a statistically significant positive impact of all segments of entrepreneurial orientation and of quantitative and qualitative effects of business performance was identified in both years, with the exception of autonomy in 2019, where no significant impact was found on business performance.

\section{Conclusions}

Croatian economy has been stagnating and a large number of companies that were included in the 2016 research have ceased to exist. Statistical analysis could not reliably present the impact of risk-taking on business performance, neither the impact of autonomy on innovativeness and business performance, and that is the difference between the 2016 and the 2019 research. This study expands on the previous findings and offers a theoretical contribution, with a series of management implications. Highly educated labor is crucial for the development of autonomy and hence for the development of innovativeness in companies. Long-term cooperation between companies and their stakeholders, promoted by the system of corporate management, furthers the autonomy and risk-taking in producing sophisticated high-quality products. There are several important implications of this research for entrepreneurs, which suggest the development of autonomy in companies. The research indicates that entrepreneurs have no risk propensity, they are not willing to take risks in order to bring prosperity to the company. Nevertheless, entrepreneurs are faced with a dynamic market and have to take significant risks, particularly in trying to increase exports into the international market. Risk-taking also prompts entrepreneurs to cooperate with outside stakeholders in realizing new business opportunities on the market.

The research has two main findings. Firstly, entrepreneurial orientation positively and directly impacted innovativeness and business performance, and secondly, this impact was not significantly changed in the 2019 in relation to 2016. Positive and statistically significant impact was identified on all segments of entrepreneurial orientation (proactiveness, risk-taking, and autonomy); on innovativeness (product innovativeness, process innovativeness, and business system innovativeness; and on business performance (quantitative and qualitative effects) in both 2016 and 2019. The only exception was that no significant impact was found on autonomy and on any other innovativeness segment or business performance in the year 2019.

There are, however, some important limitations of this empirical research. Its results can be considered relevant only for the companies included in this research and can not be generalized for all companies. Hence these limitations refer only to the Croatian companies in the sample. The data was collected during 2016 and 2019, so the variables and the results are limited to these two points in time. The research was carried out in the period in which the Croatian economy was slowly coming out of the crisis, and these circumstances certainly influenced 


\section{ENTREPRENEURSHIP AND SUSTAINABILITY ISSUES}

ISSN 2345-0282 (online) http://jssidoi.org/jesi/ 2021 Volume 9 Number 2 (December)

http://doi.org/10.9770/jesi.2021.9.2(10)

some of the answers to the questionnaire. Furthermore, the applied methodology in the research can also be considered a limitation, since not all the factors were included, e.g. quality factor, research and development factors, etc. However, despite these empirical limitations of the research, the validity of the theory has been confirmed. The empirical contribution has been achieved by defining the impact of entrepreneurial orientation on the innovativeness and business performance of a company. The conclusions of both theoretical and empirical research testify to the importance of entrepreneurial orientation and innovativeness in creating the value and solutions which would foster the development of companies and the entire economy. To boost their business performance, companies should enhance their proactiveness and autonomy within the organization, take more risks and venture into innovative projects, to improve their competitive advantage on the market. The results of the research confirm that entrepreneurial orientation is a major vehicle of an innovative company. Future research should use a larger sample of companies, in more than one country, to identify similarities and differences in the relations between entrepreneurial orientation, innovativeness, and business performance of a company. The statistical set in this research did not include micro-enterprises, so a part of the future research could also contrast entrepreneurial orientation, innovativeness, and business performance in micro-enterprises as opposed to bigger companies, in several countries.

\section{References}

Acs, Z. J. (2006). How is entrepreneurship good for economic growth? Innovations Technology, Governance, Globalization, 1(1), 97-107. https://doi.org/10.1162/itgg.2006.1.1.97

Acs, Z. J., Audretsch, D. B., \& Lehmann, E. E. (2013). The knowledge spillover theory of entrepreneurship. Small Business Economics, 41(4), 757-774. https://doi.org/10.1007/s11187-013-9505-9

Acs, Z. J., Desai, S. \& Hessels, J. (2008). Entrepreneurship, economic development and institutions. Small Business Economics, 31 (3), 219-234. https://doi.org/10.1007/s11187-008-9135-9

Alegre, J., \& Chiva, R. (2013). Linking Entrepreneurial Orientation and Firm Performance: The Role of Organizational Learning Capability and Innovation Performance. Journal of Small Business Management, 51(4), 491-507. https://doi.org/10.1111/jsbm.12005

Anderson, B. S., Kreiser, P. M., Kuratko, D. F., Hornsby, J. S., \& Eshima, Y. (2015). Reconceptualizing entrepreneurial orientation. Strategic Management Journal, 36 (10), 1579-1596. https://doi.org/10.1002/smj.2298

Audretsch, D. B., \& Thurik, A. R. (2001). What's new about the new economy? Sources of Growth in the Managed and Entrepreneurial Economies. Industrial and Corporate Change, 10(1), 267-315. https://doi.org/10.1093/icc/10.1.267

Baumol, W. J. (1990). Entrepreneurship: Productive, unproductive, and destructive. Journal of Political Economy, 98(5, Part 1), 893-921. https://doi.org/10.1086/261712

Bernoster, I., Mukerjee, J., \& Thurik, R. (2020). The role of affect in entrepreneurial orientation. Small Business Economics, 54(1) 235256. https://doi.org/10.1007/s11187-018-0116-3

Bjørnskov, C., \& Foss, N. J. (2013). How strategic entrepreneurship and the institutional context drive economic growth. Strategic Entrepreneurship Journal, 7(1), 50-69. https://doi.org/10.1002/sej.1148

Carlsson, B., Braunerhjelm, P., McKelvey, M., Olofsson, C., Persson, L., \& Ylinenpää, H. (2013). The evolving domain of entrepreneurship research. Small Business Economics, 41(4), 913-930. https://doi.org/10.1007/s11187-013-9503-y

Certo, T.S., Moss, T. W., \& Short, J. (2009). Entrepreneurial orientation: An applied perspective. Business Horizon, 52, 319-324. https://doi.org/10.1016/j.bushor.2009.02.001 


\section{ENTREPRENEURSHIP AND SUSTAINABILITY ISSUES}

ISSN 2345-0282 (online) http://jssidoi.org/jesi/ 2021 Volume 9 Number 2 (December)

http://doi.org/10.9770/jesi.2021.9.2(10)

Covin, J. G., Eggers, F., Kraus, S., Cheng, C. F., \& Chang, M. L. (2016). Marketing-related resources and radical innovativeness in family and non-family firms: A configurational approach. Journal of Business Research, 69(12), 5620-5627. https://doi.org/10.1016/j.jbusres.2016.03.069

Covin, J. G., \& Lumpkin, G. T. (2011). Entrepreneurial orientation theory and research: Reflections on a needed construct. Entrepreneurship Theory and Practice, 35(5), 855-872. https://doi.org/10.1111/j.1540-6520.2011.00482.x

Covin, J. G. \& Miller, D. (2014). International entrepreneurial orientation: Conceptual considerations, research themes, measurement issues, and future research directions. Entrepreneurship Theory and Practice, 38(1), 11-44. https://doi.org/10.1111/etap.12027

Covin, J., \& Slevin, D. (1989). Strategic management of small firms in hostile and benign environments. Strategic Management Journal, 10(1), 75-87. https://doi.org/10.1002/smj.4250100107

Covin, J. G., \& Wales, W. J. (2012). The measurement of entrepreneurial orientation. Entrepreneurship Theory and Practice, 36(4), 677702. https://doi.org/10.1111/j.1540-6520.2010.00432.x

Covin, J. G. \& Wales, W. J. (2019). Crafting High-Impact Entrepreneurial Orientation Research: Some Suggested Guidelines. Entrepreneurship Theory and Practice, 43 (1), 3-18. https://doi.org/10.1177/1042258718773181

Dai, L., Maksimov, V., Gilbert, B.A., \& Fernhaber, S. A. (2014). Entrepreneurial orientation and international scope: The differential roles of innovativeness, proactiveness, and risk-taking. Journal of Business Venturing, 29(4), 511-524. https://doi.org/10.1016/j.jbusvent.2013.07.004

Desai, S., Acs, Z. J., \& Weitzel, U. (2013). A model of destructive entrepreneurship: Insight for conflict and postconflict recovery. Journal of Conflict Resolution, 57(1), 20-40. https://doi.org/10.1177/0022002712464853

Diánez-González, J. P., \& Camelo-Ordaz, C. (2017). The influence of the structure of social networks on academic spin-offs' entrepreneurial orientation. Industrial Marketing Management, 80, 84-98. https://doi.org/10.1016/j.indmarman.2017.12.009

Ejdys, J. (2016). Entrepreneurial Orientation vs. Innovativeness of Small and Medium Size Enterprises. Journal of Engineering, Project, and Production Management, 6(1), 13-24. https://doi.org/10.32738/jeppm.201601.0003

George, B. A., \& Marino, L. (2011). The epistemology of entrepreneurial orientation: Conceptual formation, modeling, and operationalization. Entrepreneurship Theory and Practice, 35(5), 989-1024. https://doi.org/10.1111/j.1540-6520.2011.00455.x

Głodowska, A., Maciejewski, M., \& Wach, K. (2019). How Entrepreneurial Orientation Stimulates Different Types of Knowledge in the Internationalisation Process of Firms from Poland? Entrepreneurial Business and Economics Review, 7(1), 6173. https://doi.org/10.15678/eber.2019.070104

Grilo, I., \& Thurik, R. (2005). Latent and actual entrepreneurship in Europe and the US: some recent developments. The International Entrepreneurship and Management Journal, 1(4), 441-459. https://doi.org/10.1007/s11365-005-4772-9

Gupta, V.K, \& Gupta, A. (2015). Relationship between Entrepreneurial Orientation and Firm Performance in Large Organizations over Time. Journal of International Entrepreneurship, 13(1), 7-27. https://doi.org/10.1007/s10843-014-0138-0

Guzmán, C., Santos, F.J. \& Barroso, M.d.1.O. (2020). Analysing the links between cooperative principles, entrepreneurial orientation and performance. Small Business Economics, 55(4), 1075-1089. https://doi.org/10.1007/s11187-019-00174-5

Henning, M., \& McKelvey, M. (2020). Knowledge, entrepreneurship and regional transformation: contributing to the Schumpeterian and evolutionary perspective on the relationships between them. Small Business Economics, 54(2), 495-501. https://doi.org/10.1007/s11187$\underline{018-0030-8}$

Herrmann, A. M. (2019). A plea for varieties of entrepreneurship. Small Business Economics, 52(2), 331-343. https://doi.org/10.1007/s11187-018-0093-6

Hessels, J., van Gelderen, M., \& Thurik, R. (2008). Entrepreneurial aspirations, motivations, and their drivers. Small Business Economics, 31(3), 323-339. https://doi.org/10.1007/s11187-008-9134-x 


\section{ENTREPRENEURSHIP AND SUSTAINABILITY ISSUES}

ISSN 2345-0282 (online) http://jssidoi.org/jesi/

2021 Volume 9 Number 2 (December)

http://doi.org/10.9770/jesi.2021.9.2(10)

Ireland, R. D. Covin, J. G. \& Kuratko, D. F. (2009). Conceptualizing Corporate Entrepreneurship Strategy. Entrepreneurship Theory and Practice, 33(1), 19-46. https://doi.org/10.1111/j.1540-6520.2008.00279.x

Ismail, K., Anuar, M. A., Wan Omar, W. Z., Aziz, A. A., Seohod, K., \& Akhtar, C. S. (2015). Entrepreneurial intention, entrepreneurial orientation of faculty and students towards commercialization. Procedia-Social and Behavioral Sciences 181,349-355. https://doi.org/10.1016/j.sbspro.2015.04.897

Khanagha, A., Dehkordi, A.M., Zali, M. R., \& Hejazi, S. R. (2017). Performance implications of entrepreneurial orientation at public research and technology institutions. Entrepreneurship and Sustainability Issues, 4 (4), 601-610. https://doi.org/10.9770/jesi.2017.4.4(15)

Khedhaouria, A., Gurău, C., \& Torrès, O. (2015). Creativity, self-efficacy, and small-firm performance: the mediating role of entrepreneurial orientation. Small Business Economics, 44, (3), 485-504. https://doi.org/10.1007/s11187-014-9608-y

Killa, M.F. (2014). Effect of Entrepreneurial Innovativeness Orientation, Product Innovation, and Value Co-Creation on Marketing Performance. Journal of Research in Marketing, 2(3), 198-204. https://doi.org/10.17722/jorm.v2i3.73

Lumpkin, G.T., \& Dess, G.G. (1996). Clarifying the entrepreneurial orientation construct and linking it to performance. Academy of Management Review, 21(1), 135-172. https://doi.org/10.5465/amr.1996.9602161568

Lumpkin, G.T., \& Dess, G.G. (2001). Linking two dimensions of entrepreneurial orientation to firm performance. Journal of Business Venturing, 16(5), 429-451. https://doi.org/10.1016/s0883-9026(00)00048-3

Lumpkin, G.T. Moss, T.W., Gras, D. M., Kato, S., \& Amezcua, A. S. (2013). Entrepreneurial processes in social contexts: how are they different, if at all?. Small Business Economics, 40(3), 761-783. https://doi.org/10.1007/s11187-011-9399-3

Luu, N. \& Ngo, L. V. (2019). Entrepreneurial orientation and social ties in transitional economies. Long Range Planing, 52 (1), 103-116. https://doi.org/10.1016/j.lrp.2018.04.001

Malerba, F., \& McKelvey, M. (2020). Knowledge-intensive innovative entrepreneurship integrating Schumpeter, evolutionary economics, and innovation systems. Small Business Economics 54(2), 503-522. https://doi.org/10.1007/s11187-018-0060-2

Miller, D. (2011) Miller (1983) Revisited: A reflection on EO research and some suggestions for the future. Entrepreneurship Theory and Practice, 35(5), 873-894. https://doi.org/10.1111/j.1540-6520.2011.00457.x

Nybakk, E. (2012). Learning orientation, innovativeness and financial performance in traditional manufacturing firms: a higher-order structural equation model. International Journal of Innovation Management, 16(5), 28. https://doi.org/10.1142/s1363919612003873

OECD \& Eurostat (2005), Oslo Manual - Guidelines for collecting and interpreting innovation data 3rd Edition. OECD Publishing, Paris, France.

Perez-Luno, A., Wiklund, J., \& Valle Cabrera, R. (2011). The dual nature of innovative activity: How entrepreneurial orientation influences innovation generation and adoption. Journal of Business Venturing, $26(5)$, 555-571. https://doi.org/10.1016/j.jbusvent.2010.03.001

Presutti, M., Boari, C., Majocchi, A., \& Molina-Morales X. (2017). Distance to customers, absorptive capacity and innovation in high-tech firms: The dark face of geographical proximity. Journal of Small Business Management, 57(2), 343-361. https://doi.org/10.1111/jsbm.12323

Presutti, M., \& Odorici, V. (2019). Linking entrepreneurial and market orientation to the SME's performance growth: the moderating role of entrepreneurial experience and networks. International Entrepreneurship and Management Journal, 15(3), 697-720. https://doi.org/10.1007/s11365-018-0533-4

Raats, R. \& Krakauer, P. (2020). International Entrepreneurial Orientation: Exploring the Brazilian Context. Entrepreneurial Business and Economics Review, 8(1), 51-69. https://doi.org/10.15678/eber.2020.080103

Rauch, A., Wiklund, J., Lumpkin, G. T., \& Frese, M. (2009). Entrepreneurial orientation and business performance: An assessment of past research and suggestions for the future. Entrepreneurship Theory and Practice, 33(3), 761-787. https://doi.org/10.1111/j.15406520.2009.00308.x 


\section{ENTREPRENEURSHIP AND SUSTAINABILITY ISSUES}

ISSN 2345-0282 (online) http://jssidoi.org/jesi/

2021 Volume 9 Number 2 (December)

http://doi.org/10.9770/jesi.2021.9.2(10)

Rosenbusch, N., Brinckmann, J., \& Bausch, A. (2011). Is innovation always beneficial? A meta-analysis of the relationship between innovation and performance in SMEs. Journal of Business Venturing, 26(4), 441-457. https://doi.org/10.1016/j.jbusvent.2009.12.002

Schumpeter, J. A. (1934). The theory of economic development. Cambridge, MA: Harvard University Press.

Singer, S. Šarlija, N. Sanja Pfeifer, S., \& Oberman Peterka, S. (2018). What makes Croatia a (non)entrepreneurial country?, Global entrepreneurship monitor Croatia, 2017, CEPOR, SMEs and Entrepreneurship Policy Center, Retrieved May 9, 2020, from http://www.cepor.hr/wp-content/uploads/2015/03/EN-GEM-2017-za-web.pdf

Sobel, R. S. (2008). Testing Baumol: institutional quality and the productivity of entrepreneurship. Journal of Business Venturing, 23(6), 641-655. https://doi.org/10.1016/j.jbusvent.2008.01.004

Šlogar \& Bezić. (2020). The relationship between entrepreneurial orientation and innovativeness in Croatian companies. Poslovna izvrsnost - Business excellence 14(2), 71-87. https://doi.org/10.22598/pi-be/2020.14.2.71

Thanos, I. C., Dimitratos, P., \& Sapouna, P. (2017). The implications of international entrepreneurial orientation, politicization, and hostility upon SME international performance. International Small Business Journal, 35 (4), 495-514. https://doi.org/10.1177/0266242616641749

Todorovic, Z.W., McNaughton, R.B., \& Guild, P. (2011). ENTRE-U: An entrepreneurial orientation scale for universities. Technovation, 31(2-3), 128-137. https://doi.org/10.1016/j.technovation.2010.10.009

Tremml, T. (2019). Linking to worlds? Entrepreneurial orientation in public entreprises: a systematic review and reseacrh agenga. Annals of Public and Cooperative Economics, 90(1), 25-51. https://doi.org/10.1111/apce.12214

Wales, W., Wiklund, J., \& McKelvie, A. (2015). What about new entry? Examining the theorized role of new entry in the entrepreneurial orientation-performance relationship. International Small Business Journal Researching Entrepreneurship, 33(4), 351-373. https://doi.org/10.1177/0266242613506023

Wales, W. J. (2016). Entrepreneurial orientation: A review and synthesis of promising research directions. International Small Business Journal: Researching Entrepreneurship, 34(1), 3-15. https://doi.org/10.1177/0266242615613840

Wiklund, J., \& Shepherd, D. A. (2011). Where to from here? EO-as-experimentation, failure, and distribution of outcomes. Entrepreneurship Theory and Practice, 35(5), 925-946. https://doi.org/10.1111/j.1540-6520.2011.00454.x

Wong, S. K. S. (2012). The influences of entrepreneurial orientation on product advantage and new product success. Journal of Chinese Entrepreneurship, 4(3), 243-262. https://doi.org/10.1108/17561391211262175

Zahra S, A., Wright, M., \& Abdelgawad S. G. (2014). Contextualization and the advancement of entrepreneurship research. International Small Business Journal: Researching Entrepreneurship, 32(5), 479-500. https://doi.org/10.1177/0266242613519807

Helena ŠLOGAR PhD, Assistant Professor at the Libertas International University, Zagreb, Croatia. She teaches multiple undergraduate and graduate courses on entrepreneurship, management, innovativeness and business negotiations. Her scientific interests include entrepreneurship, management, innovativeness, business negotiations and international business.

ORCID ID: $\underline{\text { https://orcid.org/0000-0002-7240-1140 }}$ 
ENTREPRENEURSHIP AND SUSTAINABILITY ISSUES

ISSN 2345-0282 (online) http://jssidoi.org/jesi/

2021 Volume 9 Number 2 (December)

http://doi.org/10.9770/jesi.2021.9.2(10)

Make your research more visible, join the Twitter account of ENTREPRENEURSHIP AND SUSTAINABILITY ISSUES: @Entrepr69728810

Copyright (C) 2021 by author(s) and VsI Entrepreneurship and Sustainability Center

This work is licensed under the Creative Commons Attribution International License (CC BY).

http://creativecommons.org/licenses/by/4.0/

c) (i) Open Access 